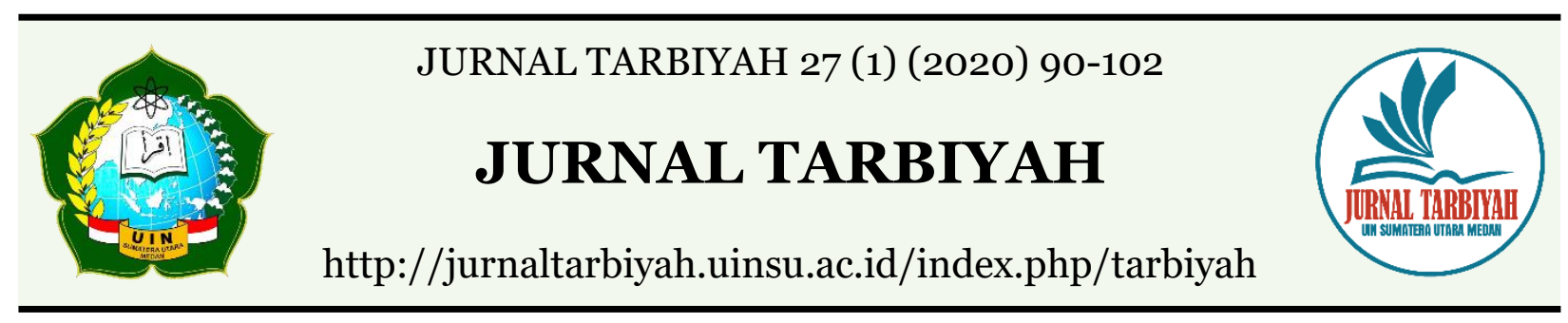

\title{
THE ROLE OF RELIGIOUS EDUCATION AND UTILIZATION DIGITAL TECHNOLOGY FOR IMPROVING THE QUALITY IN SUSTAINABILITY MADRASA
}

\author{
Siskandar \\ Institut PTIQ (Perguruan Tinggi Ilmu Al-Qur'an) Jakarta, Indonesia \\ Email : siskandari2000@yahoo.com
}

DOI : 10.30829/tar.v27i1.675

Accepted: March 29th, 2020. Approved: June 25th, 2020. Published: June 30th, 2020

\begin{abstract}
This study aims to reveal the role of religious education and the use of digital technology in improving the quality of sustainability Madrasa in Indonesia. The research method used is the study of literature. Previous studies only focused on the challenges and role of Islamic education in the digitalization era. The novelty of the research lies in the collaboration of Islamic education theory and new media theory in particular the use of digital technology in improving the quality of Madrasas sustainability in Indonesia. It is essential to know how contemporary Islamic education and digital technology can be developed as crucial factors in Madrasas' sustainability to face challenges in the current digital Era. The results of the study explained that the strengths, as well as the characteristics possessed by Madrasas, are the values of Islamic religiosity that can create a foundation of good character and behavior for the next generation of the nation. To face competition, improve quality, and survive in the world of education, Madrasas must be able to make the best use of digital technology in Madrasah governance, create digital libraries, improve the performance of teachers who are technology literate, and the application of digital technology in learning practices in Madrasa Ibtidaiyah (MI ), Madrasa Tsanawiyah (MTS), and Madrasa Aliyah (MA).
\end{abstract}

Keywords: Education, Religion, Digital, Madrasa, Sustainability 


\section{INTRODUCTION}

The development of Digital Science and Technology resulted in significant changes in people's behavior. The need for religious values and technological progress in education in schools is a challenge for educational institutions to provide solutions to the socio-economic and cultural dynamics in society. Advances in education and technology have also led to the transformation of teaching models. Therefore, education has become an essential part of the decades to date (Taskiran, 2017). Even the use of technology in the field of education enables distance learning methods for students and makes the world of student learning smaller so that everyone can access global classroom education (Mattar, 2018; Singh, 2020). The assistant technology used to develop literacy skills is also intended for literacy in students with physical disabilities (Stauter et al, 2019). Various negative influences from the environment, demanding the world of education to tighten further and strengthen the education system and religious values as the initial foundation for students who demand knowledge and are the next generation who have great potential for national development. While the utilization of Information Technology and Technology is believed to be able to expand access to services, expand access to education services, and sustainably improve the quality of education.

According to Suyanto and Abas (2001), education quality is one of the problems in the world of education. According to Law Number 20 of 2003 concerning the National Education System and Government Regulations as the implementer, Madrasas especially Madrasa Aliyah (MA) (equivalent to senior high school or vocational high school) is part of the national education system whose he same rights and obligations, namely; in the context of educating the life of the nation, realizing the goals of national education by taking into account the stages of student development and their suitability to the environment, national development needs, development of science and technology and the arts.

Based on data from the Directorate of Islamic Education and the Ministry of Religion of the Republic of Indonesia until 2019, there were 78 thousand more Madrasas scattered in Indonesia. A total of 24,951 are Madrasa Ibtidaiyah (MI) (equivalent to primary school). Then 28 thousand are Raudhatul Athfal (equivalent to kindergarten), 17,363 are Madrasah Tsanawiyah (MTS) (equivalent to junior high school), and the rest is $8,165 \mathrm{MA}$.

Islamic religious education is one of the most strategic instruments for introducing insights into sustainable development to Madrasa students because the religion of Islam 
is 'rahmatan lil alamin' (a blessing for the entire contents of the universe). Therefore, the role of Islamic religious education is needed to improve the quality of sustainable beer Madrasa. It is also due to the enthusiasm of Islamic education that always teaches harmony and wisdom in the life that becomes a fundamental basis for designing educational curricula with sustainable development as the core curriculum in Madrasa.

Madrasa that has quality in a sustainable manner, and the role of technology in the era of digitalization is a demand of the Indonesian people as a vehicle to produce human resources that are qualified and able to compete globally. Therefore, the effort to achieve this requires strategies, concrete, and operational steps carried out continuously that refer to the National Education Standards (SNP) and Islamic values. As the goal of national development in education in the 2014-2019 government period is clearly stated in the fifth Nawa Cita, which is to improve the quality of life of Indonesian people through improving the quality of education and training with the Smart Indonesia Program. The results are also written in the 2015-2019 National Medium-Term Development Plan (RPJMN). While internationally, the development goals in the field of education are contained in the Sustainable Development Goals (SDGs), especially in the fourth goal, which is to ensure an inclusive and equitable quality of education, as well as promoting life-long learning opportunities for all.

\section{LITERATURE REVIEW}

\section{Basic Concepts of Madrasa Quality and Islamic Education}

Madrasa comes from Arabic, which has the same meaning or equivalent to the word in Indonesian, namely school (Ministry of Religion of the Republic of Indonesia, 2005). Madrasa is a place where formal teaching-learning processes take place that has their curriculum, methods, and ways of teaching that are unique and different from other formal schools (Steenbrink, 1991). The specific characteristic referred to is the method of teaching religious education that emphasizes Islamic values in the form of learning to recite the Al Qur'an, practical worship lessons, teaching Tauhid, Tafsir, Islamic Tarikh, and Arabic. After that, then general lessons and skills. In terms of education, madrasa was initially synonymous with learning to recite the Al Qur'an, the level of recitation at the elementary level, and the study of advanced books.

In education at the Madrasah level, the education process can be said to be of high quality if the coordination and harmonization and integration of Madrasah inputs (teachers, students, curriculum, money, and equipment) are carried out in harmony to 
create a pleasant learning situation, be able to encourage motivation for students and improve interest in learning, and being able to empower students. The word empower has an understanding that students not only master the knowledge taught by the teacher, but that knowledge has become a charge of conscience that is practiced in daily life (Suhirman, 2015)

According to Murgatroyd, Stephen, and Morgan (1994), the quality of education is categorized into four types, namely: 1) the quality of inputs includes human resources (HR) and non-HR; 2) the quality of the process includes the decision making process, the institutional management process, the program management process, the teaching and learning process, the monitoring process and the evaluation process; 3 ) the quality of education output includes the achievement of graduating an education with high value indicators; and 4) the quality of outcomes, namely graduation with work carried out in accordance with the department and expertise possessed by the education graduate.

\section{Islamic Views on Utilization of Technology in the Field of Education}

The relationship between technology and education is a precursor of the relationship between technology and religious education because religious education is strongly influenced by technological progress (Furat, 2014). The progress that is a contemporary issue makes it necessary to integrate teaching skills, curriculum, educational environment, methods, and educational tools and materials with technology in religious education. This dimension of integration must be analyzed to achieve effective religious education. It is the reason why people should approach religious education from a new, better perspective. (Bayraktar, 2020)

Digital-based education governance can explore ways of digital technology in changing educational experiences (Landri, 2018). Utilization of technology as a medium of learning to improve the quality of education can be categorized into four groups, namely: 1) utilizing computers as a medium for the delivery of instructional materials (Computer Assisted Instructional (CAI); 2) media for the distribution of teaching materials through the internet network; and 3) utilizing information technology as a medium of communication with experts, or speakers, or other students (teleconferences). Broadly speaking, the use of technology in the educational process includes 1) management of information systems that support the functions of operations, management, and decision making to enable the flow of information to run quickly and accurately; 2) learning media in the form of e-learning and the use of computers as 
interactive media capable of stimulating thoughts, feelings, and interests in the learning process provided by the teacher; 3 ) learning media that can improve the effectiveness and efficiency of the teaching and learning process of education; 4) Life skills, both application and programming language. (DePorter \& Hernacki, 1999; Purbo, 2002; Husaini, 2014; Andri, 2017; Nurdyansyah, 2017)

It is interesting that Al Qur'an strongly encourages people to pay attention to the relationship between Islamic teachings and the knowledge and uses that we call Science and Technology (Science and Technology). As mentioned in verse Jonah, verse 101, "Do intensive research on what is in the sky and what is on earth." The Islamic view of technology can be known by its principles as stated by Rais (1998) contained in the AlMujadalah verse 11, which means, "... Allah will lift up Believers among you who have knowledge of some degree."

\section{RESEARCH METHOD}

This study uses a literature review writing method. Based on the results of studies from previous research and documentation data from various sources, it is hoped that research can reveal the role of religious education and digital technology in improving the quality of sustainable Madrasa. This article is based on the search and review of peerreviewed articles on religious education and the use of technology in education. This research has a novelty in terms of revealing more specific research results on the role of religious education and digital technology following the development of the current world of education.

\section{RESULT}

\section{The Role of Islamic Education in Improving the Quality for Madrasa Sustainability}

Madrasa levels managed by the Ministry of Religion (Kemenag) in Indonesia are very similar to public and private schools managed by the Ministry of National Education (Kemendiknas). Although Madrasas have the characteristics and structure of schools in general, Madrasas are not supervised by the Ministry of National Education but are supervised by the Ministry of Religion (Depag) as emphasized in Presidential Decree Number 34 of 1972. Furthermore, the Presidential Decree, together with the Presidential Regulation "Presidential Instruction" Number 15 of 1974, provides all authority to the Ministry of National Education for the implementation of education and training in 
public and private schools, including the development of its educational programs (Nawawi, 1983). However, at present, it appears that the Ministry of National Education has only limited control over the school and even very little towards Madrasa.

At the beginning of its development in Indonesia, Madrasa did not have a conflict or attempt to contrast between the religious sciences and other general sciences that were universal. Conflicts are only common between one religious organization and another religious organization that has a different religious understanding, and they both set up their madrasa to socialize and develop their own ideas. According to historical records, Madrasa in Indonesia initially grew and developed at the initiative of community leaders and scholars who care about religious education. Madrasa accommodate many sociocultural-religious aspirations from the community (Fadjar, 1998). Because the initiative and funds came from non-governmental organizations, the cost of education in Madrasas was lighter. However, as its development and support from the government, then changed to the level of MI, MTS, MA (Mukhtar, 2001) and gradually accepted as one of the Islamic educational institutions that also plays a role in the development of improving the quality of education in Indonesia under the guidance of the Ministry of Religion. (Ministry of Religion of the Republic of Indonesia, 2004)

There are reasons why efforts to improve the quality of education in Indonesia are not entirely successful. Educational development strategies that have been more inputoriented, so far, rely more on the assumption when all educational inputs have been universally fulfilled, such as learning facilities and infrastructure (books and teaching materials), teacher training, and teaching staff, the educational institutions will automatically ( Madrasa) will be able to produce quality output as expected. However, the truth is, this strategy only applies to economic and industrial institutions. In terms of producing outputs, religious education that fosters morality and ethics in each individual is also needed to support the achievements of Madrasa.

To enhance the role of Islamic religious education, learning innovations in Islamic religious education to improve the quality of sustainable Madrasa must be directed towards sustainability regarding resources, environment, social, and culture. Sustainability development can teach students morality and encourage them to always be careful and remain wise in every activity that uses natural resources where religion also teaches the same thing, namely, to protect the environment and the natural surroundings. Zamroni and Rahayu (2012) explained that the right strategy to guarantee the sustainability of Madrasa is in three ways, namely 1) developing innovative learning 
paradigm-sustainability development must be in accordance with student talents, which can be done by developing KTSP (Curriculum for Education at Unit level); 2) conservation of socio-cultural values as the basis for achieving a sustainability development paradigm; and 3) the innovations needed for the creation of sustainability development vary in every school background. It is this innovation that is expected to be able to improve the quality of sustainability Madrasa, as a matter of inter-generational environmental conservation.

In the practice of learning in Madrasa, elements of sustainable development are implemented in the learning of Natural Sciences (IPA) subjects that provide insights on the environment and Islamic values related to environmental sustainability. It is what is known as the integrated Islamic education model. There are two orientations, namely the orientation of worldly life by always thinking of natural resources and the orientation of ukhrawi by always thinking of more eternal and everlasting life. As a basis for developing integrated learning, teachers must understand the principles and main objectives of the curriculum in Madrasa as well as possible. Moreover, if needed, the teacher must be given training and certification to support his competence as a professional teacher.

What is clear, the role of Islamic education requires teachers as intermediaries to provide knowledge to students in ways and techniques that are easily understood by students so that they can empower and practice themselves and the environment. The mastery of knowledge available to the teacher alone is certainly not enough, as not every knowledgeable person can effectively transform his knowledge to students. Therefore, Suhirman (2015) explains several criteria as well as the values that must be met, namely; 1) the teacher must be able to manage student activities; 2) firm in acting and placing various cases proportionally; 3) able to learn the psychological life of students in harmony with the development period at the time of teaching it; 4) responsive to various world conditions and developments that influence behavior and beliefs; and 5) are required to be fair and disciplined towards all students.

This normative basis can be used as an epistemology of Madrasa development that is contextualized to the situation and conditions in the current digitalization era. While the innovation of Islamic religious education learning in Madrasas emphasizes aspects of honesty, morality, and a sense of responsibility towards oneself, fellow humans, and the environment.

As research conducted by Suhirman (2015) confirms that the quality of education depends on the performance of Madrasas in producing educational output and can be measured from the quality, effectiveness, efficiency, innovation, and productivity. 
Religious education provided by teachers is expected to be practiced in daily life continuously so that students will develop themselves as the guidelines of Islamic values. Madrasa output quality can be said to be quality if Madrasah achievements, especially student learning, show high achievements both in academic achievements in the form of National Examination scores, scientific work, academic competitions and non-academic achievements such as honesty, courtesy, sports, arts, skills, and the other extracurricular activities.

Madrasa quality in Indonesia in the context of the results of education refers to the achievements obtained at any given time (whether at the end of every quarter, the end of the year, two or five years, or even ten years). Achievements obtained can be in the form of academic ability test results (e.g., final exams and general tests) and non-academic achievements such as dance and skills.

The role of religious education also influences intangible conditions such as an atmosphere of discipline, friendship between students and teachers, mutual respect and respect, and cleanliness.

\section{The Role of Utilization of Technology in improving the quality of Madrasa Sustainability}

Cambridge International research through the Global Education Census (2018) shows that students in Indonesia are very familiar with technology, not only in interacting but also for learning needs in schools. The study results revealed that students in Indonesia rank highest globally as users of the Information and Technology (IT) space in schools by $40 \%$. More than two-thirds or about $67 \%$ use smartphones in the classroom, and the remaining $81 \%$ to do homework (homework). It is what causes the increasing complexity of the educational process, which involves the teaching, guidance, and supervision of teachers of their students. Therefore, in the current curriculum, StudentCentered Learning is carried out, as adapted in Minister of Education and Culture Regulation (Permendikbud) number 81A concerning Implementation of the 2013 Curriculum.

A corroborating study of the importance of using technology reveals that there is a link between pedagogical content knowledge of teacher technology, teaching experience, beliefs about the role of technology in education, and perceptions about the benefits and challenges associated with its use. Teachers' perceptions about the value of technology in education classrooms include providing differentiation, offering a variety of content 
representations, increasing student motivation, and involvement, facilitating formative assessment, and developing life skills. The challenges of integrating technology include technological failure and lack of technological knowledge of teachers and students (Anderson \& Rebecca, 2020). This problem must be sought as a solution.

Technology-based learning solutions must be able to strengthen interactions between students, teachers, schools, and also outside of school. Complete literacy and learning methods alone are not enough; there needs to be a companion from both the material side and the academic team to build interactions in the teaching and learning environment.

One of the uses of technology is related to religious education input. The input of religious education is everything that must be provided because it is needed for the process to take place, including human resources (Madrasa head, teacher, administrative staff, and students) and the rest of the resources (equipment, money, money, materials, and others). Educational input in the form of software includes madrasa organizations, laws and regulations, programs, and so on. Data input can also be in the form of vision, mission, goals, and objectives to be achieved by Madrasa. Wheelen and Hunger (1995) explain that the high and low quality of inputs can be measured from the level of input readiness. The higher the level of input, the higher the quality of the input. It means that input is needed so that a religious education process can take place correctly.

The process in question is the process of decision making, the process of institutional management, the process of program management, the process of teaching and learning, and the process of monitoring and evaluation, provided that the learning process has the highest level of importance compared to other processes (Suhirman, 2015)

When referring to the background of the decline in the quality of education proposed by Mulyana (2004), namely: 1) the influence of behaviorism is still strong in the education system in Indonesia; 2) the capacity of the majority of educators in terms of lifting the basic structure of massive teaching materials is relatively low; 3) the demands of an increasingly pragmatic era, and 4) there are attitudes and positions that are less favorable for the establishment of educational democracy. In this case, the use of technology can help overcome the decline in the quality of education, as stated by Mulyana (2004). Both digital technology such as Blockchain and Big data can be used to support the education system in Indonesia, and several industries and government institutions have also done so. Skill training in using digital technology is necessary to 
improve teacher performance. The teacher must be able to master the technology needed in the teaching and learning process. Radhy's research (2019) revealed that it is essential to prepare teachers as a vital role in the teaching-learning process. Teachers must have a deep and broad understanding of subjects, understand content, and technology education. In other words, teaching together with technology means that as long as the teacher thinks about the concept of a particular subject, one must simultaneously reflect on how to make the concept of the subject understandable by students using expression technology.

Moreover, students must be given learning and knowledge regarding the use of technology that continues to develop. It is a demand of the development era where information and facilities provided by technology can be the key to success in improving the quality of sustainable Madrasas. Indeed, the integration of technology in learning and education is an inevitable part of a changing world. Sarker, Cao, Alam, and Li (2019) explain that utilizing technology is an essential part of every mode of learning. While digital technology is increasing, it has now been implemented in teaching and learning, tutorials, and laboratory work. Incorporating technology into the teaching and learning process can be an effective way to develop students and teachers to obtain better achievement results.

In the $\mathrm{Al}$ Qur'an, there are so many commands, statements, suggestions, and innuendos that substantially connect Islamic teachings with science and technology. Budiman (2017) and Harahap (2019) revealed that the role of information technology in education, besides helping students in learning also has a significant role for teachers, especially in the use of facilities to improve teaching skills, and the Al Qur'an as a guide and guide for the development of science and technology in order to strengthen faith and improve the welfare of humanity.

The government must support efforts to equalize education and use of technology that can be accessed by every Madrasa in Indonesia. For example, by funding digital libraries for students and providing digital skills training for teaching staff. The government must provide partiality guarantees to students who have physical, mental, economic, social, and geographical obstacles. It can be simply described that with the use of existing technology and support from the government both materially as well as in policy, the hope is the quality of Madrasa sustainability and the government's goal of educating the nation's children as mandated in the 1945 Constitution can be realized. Equitable education is intended to suppress educational disparity between rich and poor 
people, between urban and rural areas, between regions and gender disparity (BPS go id., 2017)

In the future, the government can implement the National Education Technology Plan as practiced by developed countries such as the United States. The aim is to reorganize the role of technology in education, articulating a vision of equality, active use, and collaborative leadership to enable learning everywhere, all the time. In this case, the plan must be able to ensure access to transformational learning experiences made possible by technology. (Thomas, 2016)

\section{CONCLUSION}

The results and discussion in the study revealed that the role of religious education that aims to improve the quality of Madrasa sustainability could shape civilized student behavior and morality. Religious education is an inseparable part of Madrasa because it is a characteristic of Madrasa and becomes a differentiator with public schools that apply universally. While the use of technology in education provides support in improving academic and non-academic achievements. Both can be the key to success in improving the quality of Madrasa in the current era of globalization.

\section{REFERENCES}

Anderson, Susan E., and Rebecca S. Putman. (2020). "Special education teachers' experience, confidence, beliefs, and knowledge about integrating technology." Journal of Special Education Technology 35, no. 1: 37-50.

Bayraktar, Muhammet Mustafa. (2020)."Evaluation of Studies in Technology in Religious Education Published in Turkey." In Enriching Teaching and Learning Environments With Contemporary Technologies, pp. 241-257. IGI Global.

Badan Pusat Statistik (BPS). (2017). Potret Pendidikan Indonesia: Statistik Pendidikan 2017 [A Portrait of Indonesian Education: Education Statistics 2017]. Jakarta: Badan Pusat Statistik.

Budiman, Haris. (2017). "Peran teknologi informasi dan komunikasi dalam pendidikan [The role of information and communication technology in education]." AlTadzkiyyah: Jurnal Pendidikan Islam 8, no. 1: 31-43.

Bobby DePorter. (1999). Quantum Learning. Jakarta: Kaifa. 
Cambridge International. Org., Global Education Census Survey Report. (2018). https://www.cambridgeinternational.org/Images/514611-global-educationcensus-survey-report.pdf

Departemen Agama Republik Indonesia (Depag RI). (2005). Pendidikan Islam dan Pendidikan Nasional, Paradigma Baru [Islamic Education and National Education, New Paradigm]. Jakarta: Dirjen Agama Islam.

Departemen Agama Republik Indonesia (Depag RI). (2004). Sejarah Pendidikan Islam [History of Islamic Education]. Jakarta: Raja Grafindo Persada.

Fadjar, Malik. (1998). Madrasah dan Tantangan Modernitas. Bandung: Mizan.

Furat, Murat, and İlyas Eker. (2014). "Computer-aided experimental modeling of a real system using graphical analysis of a step response data." Computer Applications in Engineering Education 22, no. 4: 571-582.

Harahap, Lelyna. (2019). "Peran teknologi informasi dan komunikasi dalam pendidikan [The role of information and communication technology in education].": 375-381.

Husaini. (2014). Pemanfaatan Teknologi Informasi dalam Bidang Pendidikan (Eeducation) [Utilization of Information Technology in the Field of Education], Jurnal Mikrotik 2.1 pp. 1-5.

Karel A. Stenbrink. (1991). Pesantren, Madrasah, Sekolah [Pesantren, Madrasahs, School]. Jakarta: LP3ES.

Landri, Paolo. Digital Governance of Education: Technology, standards and Europeanization of education. Bloomsbury Publishing, (2018).

Mukhtar, Maksum . (2001). Sejarah Pendidikan Islam. Logos Wacana Ilmu [History of Islamic Education. Logos of Science Discourse], Jakarta.

Mattar, Joao. (2018). "Constructivism and connectivism in education technology: Active, situated, authentic, experiential, and anchored learning." RIED. Revista Iberoamericana de Educación a Distancia 21, no. 2.

Mulyana, Deddy. (2004). Metodologi Penelitian Kualitatif, Paradigma Baru Ilmu Komunikasi dan Ilmu Sosial Lainnya [Qualitative Research Methodology, New Paradigm of Communication Studies and Other Social Sciences], Bandung: PT Remaja Rodakarya.

Murgatroyd, Stephen dan Morgan, Colin. (1994). Total Quality Management and The School. Buckingham: Open University Press.

Nawawi, Haidar (1983). Perundang-undangan Pendidikan [Educational legislation]. Jakarta: Ghalia Indonesia. 
Nurdyansyah, Nurdyansyah, Pandi Rais, and Qorirotul Aini. (2017). "The Role of Education Technology in Mathematic of Third Grade Students in MI Ma'arif Pademonegoro Sukodono." Madrosatuna: Journal of Islamic Elementary School 1, no. 1: 37-46.

Purbo, Onno W. (2002). Teknologi e-Learning. Jakarta: Elex Media Komputindo.

Radhy, Zainb Hassan. (2019). "Application of Multiply Regression Linear Model and New Technology Method in Estimating Learning and Education of Students." International Electronic Journal of Mathematics Education 14, no. 1: 87-90.

Rais, M.A. (1998). Al Islam dan Iptek [Al Islam and Science and Technology], Jakarta, Perumus Fakultas Teknik UMJ.

Sarker, Md Nazirul Islam, Min Wu, Qian Cao, GM Monirul Alam, and Dan Li. (2019). "Leveraging Digital Technology for Better Learning and Education: A Systematic Literature Review." International Journal of Information and Education Technology 9, no. 7: 453-461.

Suhirman, Suhirman. (2015). "Peningkatan Mutu Madrasah Berkelanjutan (Sustainability) Berbasis Kinerja Guru [Improving the Quality of Sustainable Madrasas (Sustainability) Based on Teacher Performance]." Biota 8, no. 2: 157-172. Suyanto dan M.S. Abbas. (2001). Wajah dan Dinamika Pendidikan Anak Bangsa [The Face and Dynamics of National Education], Yogyakarta: Adicita Karya Nusa. Singh, Meenakshi. (2020). "Impact of Technology in Indian Education System." Advance and Innovative Research: 349.

Stauter, Donna W., Judy Prehn, Megan Peters, Lynn M. Jeffries, Lorraine Sylvester, Hongwu Wang, and Carol Dionne. (2019). "Assistive Technology for Literacy in Students With Physical Disabilities: A Systematic Review." Journal of Special Education Technology 34, no. 4: 284-292.

Thomas, Susan. (2016). "Future Ready Learning: Reimagining the Role of Technology in Education. 2016 National Education Technology Plan." Office of Educational Technology, US Department of Education.

Zamroni, M. Imam, and Lies Rahayu WF. (2012). "Pengembangan Madrasah Berparadigma Pembangunan Berkelanjutan [Madrasahs Development Paradigm Sustainable Development]." Jurnal Kawistara: Jurnal Ilmiah Sosial dan Humaniora 2, no. 1. 